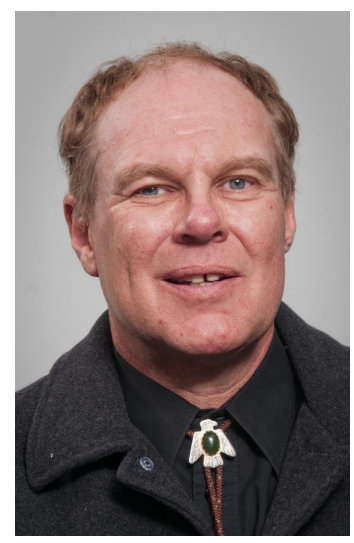

\title{
WHEN CONDUCT IS DEEMED TO OCCUR IN THE WORKPLACE AND THE LIABILITY OF EMPLOYERS FOR THE SEXUAL HARASSMENT OF ONE CO- WORKER BY ANOTHER
}

\author{
Peter McLuskie \\ School of Business \\ The Open Polytechnic of New Zealand
}

\begin{abstract}
This paper analyses the different approaches of the Employment Relations Act 2000 and the Human Rights Act 1993 as to whether sexual harassment of one co-worker by another occurs as a part of the employment relationship. It examines the Court of Appeal and the Human Rights Review Tribunal regarding the liability of the same person (Smith) for sexual harassment. The Court of Appeal upheld Smith's dismissal as it impacted on his employment relationship, while the Human Rights Review Tribunal held Smith's behaviour was not in the in the course of his involvement in employment. Reasons for the difference between the two decisions are examined, looking in particular at employer liability for the actions of co-workers, and the different ways the two Acts deal with such liability. Canadian and Australian approaches to employer liability are examined, noting consistency between the approaches in their human rights and employment legislation. It is suggested that inconsistencies between the Employment Relations Act and the Human Rights may lead to different outcomes regarding employer liability. Finally it is suggested that, given the differences between the two Acts, it would be better for matters of sexual harassment to only be dealt with under the Human Rights Act.
\end{abstract}

\section{Introduction}

It is unusual for the same factual situation to be considered under both the Employment Relations Act 2000 and the Human Rights Act 1993. Both Acts contain very similar provisions to deal with issues of discrimination and harassment, along with provisions requiring complaints to be heard under one Act or the other (but not both). Smith's conduct led to an unfair dismissal action being dismissed by the Court of Appeal, and the Human Rights Review Tribunal dismissing a complaint of sexual harassment against Smith. A key issue was whether the behaviour was employment related, with both bodies reached different conclusions. The Court of Appeal found that the Christchurch Press was entitled to dismiss Smith due to the impact of his behaviour on workplace relationships. The Human Rights Review Tribunal dismissed the complaint against Smith on the grounds that the behaviour did not occur in the course of his involvement in employment. The different approaches of the two Acts to the liability of employers for the sexual harassment by co-workers may to different results if a complaint is brought under one Act rather than the other.

\section{Smith - the facts}

The factual matrix of the Smith cases is reasonably straightforward. Smith and the complainant were coworkers. They went back to his place for lunch. During the next two hours a sexual encounter (initiated by Smith) occurred. The complainant considered the encounter was sexual harassment. On returning to work she complained to their employer, the Christchurch Press. The complaint was investigated and Smith was dismissed.

\section{Smith - the Court of Appeal decision regarding unfair dismissal}

Smith's complaint of unjustified dismissal under the Employment Relations Act was eventually heard by the Court of Appeal in Smith v Christchurch Press Company Ltd [2001] 1 NZLR 407. The Employment Court had previously held the respondent did not breach its obligations to act in a fair and reasonable manner when 
it conducted its investigation, and the sexual harassment was employment related. In reaching this decision Shaw J had applied the 'but for' test (would the sexual harassment have occurred but for the complainant's employment).

The application of the 'but for' test without further qualification was rejected by the Court of Appeal, as it could not provide a test for all circumstances.

As Mr Couch pointed out, at the extreme it could extend to all conduct, whenever occurring, involving persons who first met in an employment situation. Plainly that would permit employers to intrude too far into the private lives of employees. [Paragraph 19]

After considering the location of the conduct, the Court of Appeal held:

It is not so much a question of where the conduct occurs but rather its impact or potential impact on the employer's business, whether that is because the business may be damaged in some way; because the conduct is incompatible with the proper discharge of the employee's duties; because it impacts upon the employer's obligations to other employees or for any other reason it undermines the trust and confidence necessary between employer and employee. [Paragraph 25]

The Court of Appeal held Shaw J was correct in holding there was sufficient connection between the conduct and employment, the conduct was serious misconduct, and Christchurch Press Ltd was justified in dismissing Smith. The Court of Appeal held it was not necessary for actual adverse effects in the workplace be demonstrated, as long as there was, inevitably, a negative impact. Here it was clear to the employer that the two co-workers could not remain in the workplace without real concerns of incompatibility and safety that would seriously affect the workplace. In New Zealand it had long been recognised that employment relationships could be considered widely as far as serious misconduct was concerned.

Dismissal for serious misconduct cannot be confined to conduct in the course of employment in any but the widest sense. It has long been recognised that conduct outside the work relationship but which brings the employer or his business into disrepute may warrant dismissal: Airline Stewards \& Hostesses of NZ IUOW v Air New Zealand Ltd [1986] ACJ 462, DB Breweries Ltd v Hodgson ((unreported) AEC 68/96 14 October 1996, Judge Travis), Mussen v NZ Clerical Workers Union [1991] 3 ERNZ 368. [Paragraph 21]

\section{Smith - the Human Rights Review Tribunal decision regarding whether the sexual harassment occurred in the workplace}

While Smith unsuccessfully raised his complaint under the Employment Relations Act, the co-worker brought proceedings against both Smith and the Christchurch Press under the Human Rights Act. This complaint was eventually adjudicated upon by the Human Rights Review Tribunal in The Director Human Rights Proceedings $v$ Smith HRT 2004 Decision \# 50/04 Reference \# HRRT 09/01A.

By the time of adjudication the Christchurch Press had settled with the complainant, but no settlement had been effected between the complainant and Smith. However, to find that Smith had breached the complainant's human rights via sexual harassment under s 62, it was still necessary to show that the conduct occurred within the workplace. Despite the earlier Court of Appeal finding that the employer was justified in dismissing Smith because of the impact of his conduct on his employer's business, the Tribunal held that Smith's actions did not involve any conduct that was in the course of his involvement in employment by the Press.

To explain this discrepancy the Tribunal suggested that the wording of the Human Rights Act required the Tribunal to define the scope of employment in a narrower manner. The Tribunal argued that in considering whether Smith's behaviour occurred in the course of employment in terms of a human rights violation, it first had to consider the language of the relevant section of the Human Rights Act 1993. Section 62(2) and (3) of the Act state:

(2) It shall be unlawful for any person (in the course of that person's involvement in any of the areas to which this subsection is applied by subsection (3) of this section) by the use of language (whether written or spoken) of a sexual nature, or of visual material of a sexual nature, or by physical behaviour of a sexual nature, to subject any other person to behaviour that-

(a) Is unwelcome or offensive to that person (whether or not that is conveyed to the first-mentioned person); and

(b) Is either repeated, or of such a significant nature, that it has a detrimental effect on that person in respect of any of the areas to which this subsection is applied by subsection (3) of this section.

(3) The areas to which subsections (1) and (2) of this section apply are....

(b) Employment ...

Thus, for sexual harassment to occur, it must be in the course of that person's involvement in employment, which is not the same as saying that the behaviour occurred in the course of employment. This distinction was used to distinguish the Court of Appeal's decision on the same facts from that of the Tribunal. Next the Tribunal reviewed a variety of key international cases on whether conduct was in the course of employment:

A number of propositions emerge from this analysis of the cases we were referred to. In no particular order of importance:

(a) All the cases confirm the primary submission made on behalf of the complainant, namely that conduct can be in the course of involvement in employment even if it does not happen at the work place, or during work time, and even if the acts complained of do not involve the discharge or purported discharge of the defendant employee's responsibilities to his or her employer;

(b) It goes too far, however, to say that conduct must be in the course of involvement in employment if it would not have happened but for the fact that the complainant and the defendant are or were at some relevant time in common employment;

(c) What employees do when they are at conferences or social functions organised by an employer can amount to conduct that is in the course of employment (Stubbs; Leslie v Graham [2002] FCA 32); 
(d) There are, however, situations in which conduct that occurs between co-workers outside their normal duties and/or place of work is not conduct in the course of involvement in employment, even if it happens to occur in living premises provided for the complainant by his or her employer (Waters) or at a work related conference (Cluff);

(e) It is necessary to approach the application of section 62(2) in a manner that respects the fact that it is part of a statute dealing with human rights, and in a way that is in conformity with the objectives of the Act as a whole But in the end the particular decision in any given case as to whether conduct is in the course of involvement in employment is a question of fact not law: Tower Boot; Stubbs (we add that both Mr McKenzie and $\mathrm{Mr}$ Lawrence agreed with this proposition). [Paragraph 68]

On this basis the Tribunal concluded:

We are not persuaded that anything that occurred can realistically be said to have been authorised by the employer, or that the decision to go to a private address for lunch is something that was incidental to or naturally connected with the employment relationship between the defendant and the Press. Nor was that decision, and what happened while the parties were at his home, anything that could possibly be described as being in furtherance of any duties owed by the defendant to his employer. The conduct was not of a kind in respect of which the employer could be said (or expected) to have exercised any control over what the defendant did. In short, we find that the defendant's activities were not sufficiently related to, or associated with, his employment but were instead of a personal nature. [Paragraph 71]

When the liability for acts of sexual harassment of the employer is considered, employment must have a narrower scope under the Human Rights Act than under the Employment Relations Act, given important differences in the way the two Acts treat the manner in which employers incur liability for actions between coworkers.

\section{Definitions of Employer under the two Acts}

In one important way the Human Rights Act and the Employment Relations Act do define the employment relationship differently. Under s 2(1) of the Human Rights Act an employer includes:

(a) the employer of an independent contractor; and

(b) the person for whom work is done by contract workers under a contract between that person and the person who supplies those contract workers; and

(c) the person for whom work is done by an unpaid worker.

Under the Employment Relations Act, s 5 defines an employer as a person employing an employee or homeworker. S 6 excludes volunteers and independent contractors from the definition. Thus the Human Rights Act defines the extent of the employment relationship more widely than the Employment Relations Act, giving further reason to otherwise limit the scope of the relationship.

\section{The Human Rights Act and the liability of employers for the actions of employees}

The Human Rights Act holds employers to a high standard with regard to the sexual harassment of one coworker by another. Section 68 states:
Liability of employer and principals

(1) Subject to subsection (3) of this section, anything done or omitted by a person as the employee of another person shall, for the purposes of this Part of this Act, be treated as done or omitted by that other person as well as by the first-mentioned person, whether or not it was done with that other person's knowledge or approval. ....

(3) In proceedings under this Act against any person in respect of an act alleged to have been done by an employee of that person, it shall be a defence for that person to prove that he or she took such steps as were reasonably practicable to prevent the employee from doing that act, or from doing as an employee of that person acts of that description.

This means discriminatory behaviour of a co-worker in relation to another is deemed as being the behaviour of the employer, with the proviso that, in order to avoid liability, the employer must show it has taken such steps as were reasonably practicable to prevent the co-worker doing acts of description. All employees, whether or not they are representatives of the employer, or simply coworkers, are covered by s 68 .

In contrast, when it comes to the employer's liability for sexual or racial harassment by the employer's customers or clients, s 69(2) requires that employers inquire into the facts, and, if satisfied that a request was made or behaviour took place, take whatever steps are practicable to prevent any repetition of such a request or behaviour. The employer is only liable if, following a complaint, there is a repetition of the behaviour, and the employer has not taken whatever steps are practicable to prevent its repetition.

The provisions applying to employer liability for the actions of co-workers under the Human Rights Act are much more extensive than those applying to customers or clients. Employers are presumed liable for any discrimination committed by co-workers. Liability can only be avoided by showing pro-active attempts to prevent discrimination, whether or not it has previously occurred.

\section{The Employment Relations Act and the liability of employers for the actions of employees}

Let us now compare this with the equivalent provisions in the Employment Relations Act. S 103(d) provides than an employee has a personal grievance if "that the employee has been sexually harassed in the employee's employment". Sexual harassment is defined in s 108, which states:

(1) For the purposes of sections 103(1)(d) and 123(d), an employee is sexually harassed in that employee's employment if that employee's employer or a representative of that employer-

(a) directly or indirectly makes a request of that employee for sexual intercourse, sexual contact, or other form of sexual activity that contains-

(i) an implied or overt promise of preferential treatment in that employee's employment; or 
(ii) an implied or overt threat of detrimental treatment in that employee's employment; or

(iii) an implied or overt threat about the present or future employment status of that employee; or

(b) by-

(i) the use of language (whether written or spoken) of a sexual nature; or

(ii) the use of visual material of a sexual nature; or

(iii) physical behaviour of a sexual nature,directly or indirectly subjects the employee to behaviour that is unwelcome or offensive to that employee (whether or not that is conveyed to the employer or representative) and that, either by its nature or through repetition, has a detrimental effect on that employee's employment, job performance, or job satisfaction.

(2) For the purposes of sections 103(1)(d) and 123(d), an employee is also sexually harassed in that employee's employment (whether by a coemployee or by a client or customer of the employer), if the circumstances described in section 117 have occurred.

In situations where the an employee is sexually harassed by a supervisor, $\mathrm{s} 108$ holds the harassment is committed by the employer, as such a person is a representative of the employer.

Section 117 provides that if an employee is sexually or racially harassed by a person (not being a representative of the employer) who is in the employ of the employee's employer or who is a customer or client of the employer then, on receiving a complaint, the employer must enquire into the facts, and, if satisfied that the request was made or that the behaviour took place, take whatever steps are practicable to prevent any repetition of such a request or of such behaviour.

Employees who are not representatives of the employer are co-workers. S 118 holds it is only where there is a repetition of the behaviour and the employer has not taken whatever steps are practicable to prevent the repetition of such a request or such behaviour that the behaviour of a co-worker is deemed to be that of the employee's employer.

Thus an employer's liability for the actions of co-workers is the same as for customers and clients under the Employment Relations Act. Employers are presumed not liable unless they fail to adequately deal with complaints, and the behaviour is repeated.

Thus the Human Rights Act and the Employment Relations Act differ with regard to the liability of employers for the actions of co-workers.

\section{Employer liability for the sexual harassment of one co-worker by another - the Canadian approach}

The liability of employers for the actions of co-workers under the Human Rights Act follows the same model as in Canadian and Australian human rights legislation. The object of such legislation is the elimination of discrimination and harassment. There is an expectation employers will proactively eliminate such undesirable behaviour from the workplace. The Canadian Human Rights Act [H-6] makes the following provision with regard to sexual harassment at s 14:

(1) It is a discriminatory practice, ....

(c) in matters related to employment, to harass an individual on a prohibited ground of discrimination.

Sexual harassment

(2) Without limiting the generality of subsection (1), sexual harassment shall, for the purposes of that subsection, be deemed to be harassment on a prohibited ground of discrimination.

With regard to the liability of employers for the sexual harassment of one co-worker by another, s 65 states:

Acts of employees, etc.

(1) Subject to subsection (2), any act or omission committed by an officer, a director, an employee or an agent of any person, association or organization in the course of the employment of the officer, director, employee or agent shall, for the purposes of this Act, be deemed to be an act or omission committed by that person, association or organization.

Exculpation

(2) An act or omission shall not, by virtue of subsection (1), be deemed to be an act or omission committed by a person, association or organization if it is established that the person, association or organization did not consent to the commission of the act or omission and exercised all due diligence to prevent the act or omission from being committed and, subsequently, to mitigate or avoid the effect thereof.

Thus in Canada employers are liable unless they have "exercised all due diligence to prevent the act or omission from being committed and, subsequently, to mitigate or avoid the effect thereof".

Sexual harassment is also explicitly dealt with in s 247 of the Canada Labor Code [L-2]. The provisions of Canada's employment legislation mirror the approach taken in the equivalent provisions in human rights legislation, and detail the preventative measures employers must adopt.

\section{Robichaudv Canada (Treasury Board) [1987]}

In the leading case of Robichaud $v$ Canada (Treasury Board) [1987] 2 S.C.R. 84 the Supreme Court of Canada discussed the role of employer liability in Human Rights legislation. In overturning the Federal Court of Appeal's position that employer liability should follow the models developed in the context of criminal/quasi criminal conduct or of vicarious liability under the law of tort, the Supreme Court determined the motives or intention of those discriminating was not a central concern. Rather the Act was designed to redress socially undesirable conditions. Analysis of the remedies available under the 
Act led to the conclusion that many of the remedies would be meaningless if they were not available against employers. The Act was seen as imposing a strong statutory liability on employers for the actions of employees.

Hence, I would conclude that the statute contemplates the imposition of liability on employers for all acts of their employees "in the course of employment", interpreted in the purposive fashion outlined earlier as being in some way related or associated with the employment. It is unnecessary to attach any label to this type of liability; it is purely statutory. However, it serves a purpose somewhat similar to that of vicarious liability in tort, by placing responsibility for an organization on those who control it and are in a position to take effective remedial action to remove undesirable conditions. .... [Paragraph 17]

I should perhaps add that while the conduct of an employer is theoretically irrelevant to the imposition of liability in a case like this, it may nonetheless have important practical implications for the employer. Its conduct may preclude or render redundant many of the contemplated remedies. For example, an employer who responds quickly and effectively to a complaint by instituting a scheme to remedy and prevent recurrence will not be liable to the same extent, if at all, as an employer who fails to adopt such steps. These matters, however, go to remedial consequences, not liability. [Paragraph 19]

\section{Employer liability for the sexual harassment of one co-worker by another - the Australian approach}

In Australia the Sex Discrimination Act 1984 has similar provisions to those in Canadian and New Zealand human rights legislation. Employers are automatically liable for sexual harassment by co-workers, unless they have taken all reasonable steps to prevent the behaviour. With regard to sexual harassment s $28 \mathrm{~B}(2)$ of the Act states:

It is unlawful for an employee to sexually harass a fellow employee or a person who is seeking employment with the same employer.

Section 106 deals with the liability of employers for the acts of employees.

(1) Subject to subsection (2), where an employee or agent of a person does, in connection with the employment of the employee or with the duties of the agent as an agent: ...

(b) an act that is unlawful under Division 3 of Part II; this Act applies in relation to that person as if that person had also done the act.

(2) Subsection (1) does not apply in relation to an act of a kind referred to in paragraph (1)(a) or (b) done by an employee or agent of a person if it is established that the person took all reasonable steps to prevent the employee or agent from doing acts of the kind referred to in that paragraph.

In the case of Coyne $v$ P\&O Ports [2000] VCAT 657 the Victorian Civil and Administrative Tribunal noted that taking all reasonable steps to prevent harassment included programmes of education and re-education along with monitoring to ensure employees understood sexual harassment policies.

Australian employment legislation does not make direct provisions with regard to sexual harassment. S 351 of the Fair Work Act 2009 provides a general prohibition against discrimination with reference back to the provisions of various Acts, including the Sex Discrimination Act 1984. Thus, with regard to sexual harassment, the approach of the Sex Discrimination Act is the only relevant one.

\section{Sexual harassment and the need to first notify the employer under the Employment Relations Act}

The Employment Relations Act approach to the liability of employers for sexual harassment is at variance with the approach of the approach in human rights law and Canadian and Australian employment law. Under the Employment Relations Act employers is only liable if, following a complaint, there is a recurrence of the behaviour and the employer has not taken whatever steps are practicable to prevent the repetition of such a request or such behaviour.

While inconsistent with the approach of the Human Rights Act, this approach is entirely consistent with the approach of the Employment Relations Act. Under $\mathrm{s}$ 4(1A)(b) good faith "requires the parties to an employment relationship to be active and constructive in establishing and maintaining a productive employment relationship in which the parties are, among other things, responsive and communicative". Unless an employee communicates to an employer that harassment is occurring then the employer has no reason to presume a problem exists. Communication is also required in order for the employer to begin any formal disciplinary process in regard to the alleged harasser.

Thus employers must know about the harassment before they incur liability. Adkins v Turks Poultry Farms [1994] 2 ERNZ 368 and the appeal in Turks Poultry Farm v Adkins [1996] 1 ERNZ 374 deal with the situation where the employer did not directly know of continuing harassment. Adkins resigned in response to continued sexual harassment. She had originally made a complaint, which was investigated and upheld, with the harasser being told to cease such conduct. However Adkins was not informed of the outcome of her complaint. Though the employer believed it had ceased, the harassment continued. Adkins even told her employer the harassment had ceased.

Both the Employment Tribunal and the Employment Court found the employer liable for its failure to take the necessary steps to prevent repetition of the harassment. The Tribunal noted the effect the lack of feedback regarding her complaint had had on Adkins, leading her to believe the complaint was being treated as trivial and nothing would be done, and if she complained the harassment would only increase. The Tribunal held Adkins was ultimately not responsible for her behaviour as a result of "learned helplessness syndrome". In the Employment Court the Tribunal's decision was approved. In his decision Goddard CJ observed: 
"For reasons of policy that is not altogether easy to understand, employees (other than employees in positions of authority over other employees) are lumped in with customers and the employer also is not liable for their acts unless s 36 is satisfied." Turks Poultry Farm v Adkins [1996] 1 ERNZ 374,381 , lines $33-36$.

Employers incur liability when they fail to prevent a repetition of the behaviour, but they must first receive a complaint.

\section{Electing between the Employment Relations Act and the Human Rights Act}

When a complaint can be heard under both Acts, s112 of the Employment Relations Act and s 79A the Human Rights Act require that employees choose the Act under which they will pursue a complaint. On choosing an Act the employee's right to pursue a complaint under the other Act is extinguished. However, when making an initial complaint, the employee is under no requirement to specify the surrounding legal regime. It is sufficient the employee simply conveys the facts of what has happened to the employer. Thus on receiving the complaint, the employer will, de facto, commence any investigation on the basis of the Employment Relations Act (as this is the Act governing employment relationships in the workplace).

At this point the employer is carrying out a fair disciplinary investigation under the Employment Relations Act in regard to the alleged harasser, while ensuring it meets its obligations under s 117, lest the employer itself assumes liability for a repetition of the behaviour under s 118 .

In carrying out a disciplinary investigation into the employee the central question is the effect of the behaviour on the relationship of trust and confidence between the employer and employee. Central to this is the issue of the impact or potential impact of the employee's conduct on the employer's business, which includes the maintenance of a harmonious working environment. Smith v Christchurch Press Company Ltd [2001] 1 NZLR 407 shows this can extend to behaviours between co-workers occurring outside of the actual workplace, and of which the employer has no knowledge and would otherwise not endorse in any manner.

However, if it is open to an employer to find the behaviour of an employee warrants disciplinary action, then it is also possible for employers to finds the behaviour does not warrant disciplinary action. Amongst the grounds an employer could advance for reaching such a decision was it considered the behaviour was too far removed from the workplace (in terms of time and distance) to warrant its further intervention or involvement, and thus did not sufficiently impact upon the employment relationships in the workplace (in particular its relationship with the co-worker who engaged in the harassment). This could well be a response to harassment between co-workers occurring during the weekend following an agreement to meet during working hours, and of which the employer had no knowledge.

The ability of employers to adopt a variety of responses in disciplinary matters is seen in the recent amendment to the $\mathrm{s} 103 \mathrm{~A}$ test for justification, where an employer is seen as being able to adopt a variety of responses, based on what a fair and reasonable employer would have done in all the circumstances. Further, it is entirely possible an employer would not even investigate some interactions between employees, believing the behaviour occurred outside of the work environment, and it was not their place to resolve such private interactions.

Here a problem arises. The complainant has not yet been required to specify the legal regime under which the complaint will be heard. If the complainant is dissatisfied with the actions of an employer who fails to investigate or otherwise considers the behaviour was too far removed from the workplace (in terms of time and distance) to warrant its further intervention or involvement, and there is a further recurrence of the behaviour outside of the workplace, then the compliant has good grounds for taking action against the employer under the Employment Relations Act. In achieving legal consistency under the Act the courts would be required to consider the impact of the behaviour on the employment relationships rather than the question of the locus of the behaviour, this, after all, having been the central consideration in the initial investigation of the complaint by the employer. By showing the behaviour has impacted on the complainant, and adversely affected the plaintiff's working relationships (leading, for instance, to resignation) the plaintiff is the able to establish a presumption the employer should have taken action against the harasser (despite the employer's earlier determination that the locus of the behaviour sufficiently removed it from the workplace and did not impact on its employment relationships). To counteract the possibility of this presumption arising, an employer must therefore adopt, from the start, a very wide view as to what constitutes the employment relationship, which may well include private areas of interaction between co-workers many employers would consider to be none of their business. The question of employer liability will, inevitability, be coloured by the considerations involved in the earlier investigation of the alleged misconduct.

However, following the employer's investigation, the complainant could chose to bring the complaint under the Human Rights Act. This does give the complainant the ability to take action against the harasser as well as the employer. However the likelihood of a successful outcome is reduced, as a central question will be whether the behaviour occurred in the course of involvement in employment, which involves a narrower consideration of the employment relationship than required under the Employment Relations Act.

Thus a situation could arise where an employer is liable for the sexual harassment of a co-worker under the 
Employment Relations Act, but would not be liable under the Human Rights Act.

\section{Liability under the Human Rights Act, but not under the Employment Relations Act}

There is also the situation where an employer could be held liable for sexual harassment under the Human Rights Act, but would not be held liable under the Employment Relations Act. This is where, through employer inaction, a workplace is rife with behaviour that constitutes sexual harassment, but no employee has ever complained. Consider the following scenario, where a manager is employed to manage a particular workplace. On arrival at the workplace the new manager discovers the workplace is littered with photos of naked women, and there is a strong culture of sexist banter amongst the workforce. She determines she simply cannot work in such a backward environment and resigns on her first day of work without otherwise making any prior complaint to her employer. She now wishes to hold her employer liable for the sexual harassment that led to her resignation.

Under the Human Rights Act she will have little difficulty in holding her employer is liable, as it has clearly failed to take steps to avoid a climate of sexual harassment in the workplace. No issues will emerge as to whether the behaviour occurred in the course of employment.

Under the Employment Relations Act she will experience difficulties due to the lack of any prior complaint to the employer about the behaviour. Without a complaint E does not assume liability in regard to a complaint under $\mathrm{S}$ 103(d) (though E may still be liable under other provisions of the Act not directly related to sexual harassment).

Thus, rather than a system where there is a real election of regimes, there is in reality a system where an employer must carry out a disciplinary investigation applying the widest definitions as to whether the conduct impacted on workplace relationships under the Employment Relations Act when, were the matter to latter go before the Human Rights Review Tribunal (via election by the complainant), the conduct would be deemed to have occurred outside of the course of involvement in employment. This, after all, is what happened in the Smith cases.

\section{Conclusion}

To conclude we can see the Employment Relations Act and the Human Rights Act operate with different perceptions as to what constitutes the scope of employment. As a result of this sexual harassment may be deemed to be within the course of involvement in employment under the Employment Relations Act will not be seen as such for the purposes of the Human Rights
Act. This is in turn related to the presumption employers are liable for the sexual harassment of one co-worker by another under the Human Rights Act, a presumption not present under the Employment Relations Act. At the same time, employers may well escape liability for a culture of sexual harassment in the workplace under the Employment Relations Act if they have never actually received a formal complaint about the behaviour.

It is suggested the current regime is unsatisfactory, and leads to confusion. Legislative reform should be considered to ensure legislative consistency. This could be achieved by ensuring the provisions of the two Acts are consistent, as is the case in Canada. Alternatively the Australian model could be followed, with the Human Rights Act becoming the only applicable Act with regard to employer liability for discrimination or harassment, with the Employment Relations Act simply making approving reference to the employer's obligations under the Human Rights Act. Breaches of the Human Rights Act by a harasser would still be relevant to the Employment Relations Act.

It would still be open to an employer to suspend, dismiss or otherwise discipline the harasser for breaches of the Human Rights Act - such discipline being based on the effect of the behaviour on the employment relationship, its impact upon the employer's obligations to other employees, and any breach of the employer's policies on harassment and discrimination in the workplace. However, when it comes to the liability of employers (along with the co-worker who committed the harassment) the matter would be determined under the Human Rights Act. The liability of employers would, as in Canada and Australia, be based on the employer's failure to take proactive steps to ensure a workplace free from harassment and discrimination.

One possible system would see an employer, on receiving a complaint, forwarding it to the Human Rights Commission for investigation. The employer and Commission would then work to resolve the issue from the earliest possible opportunity. Employers could even be required to keep "harassment registers", in the same way they are currently obliged to keep accident registers. The involvement of an independent investigatory body at the earliest possible opportunity could also provide employers with some early guidance when considering how to proceed in any internal disciplinary investigation with regard to the alleged harasser.

Such legislative reform would ensure there was one easily followed set of legal rules in cases of harassment, while providing the Human Rights Commission with greater opportunities to actively pursue its educative and enforcement objectives to ensure all workplaces are free from discrimination and harassment. 